\title{
THE EFFECTS OF CONCENTRATED SALT-POOR ALBUMIN ON THE METABOLISM AND EXCRETION OF WATER AND ELECTROLYTES IN NEPHROSIS AND TOXEMIA OF PREGNANCY ${ }^{1,2}$
}

\author{
By JACK ORLOFF, ${ }^{3}$ LOUIS G. WELT, ${ }^{4}$ AND LYMAN STOWE 5 \\ (From the Departments of Internal Medicine and Obstetrics and Gynecology, Yale University \\ School of Medicine, New Haven)
}

(Submitted for publication December 3, 1949; accepted, March 6, 1950)

\section{INTRODUCTION}

Purified albumin was first prepared by Armstong and his co-workers (1) in 1940. It was hoped that it would provide a rational mode of therapy for the edema of hypoalbuminemia and serve as an experimental tool for the study of the formation of edema.

Numerous investigators have described its use as a diuretic in nephrosis (2-6), cirrhosis of the liver (7-9), idiopathic hypoalbuminemia (10), and other conditions (10). In general the results have been extremely variable despite the fact that albumin induces the same initial hemodynamic events in all patients. Goodyer, Peterson, and Relman (11) have shown that normal subjects who experience similar changes in circulatory dynamics actually have a depression of salt excretion when concentrated albumin is administered intravenously. This has been confirmed by Welt and Orloff (12) under somewhat different conditions. However, the latter were able to augment urine flow profoundly when the albumin was introduced as an approximately iso-osmotic solution.

In the past the diuresis which occurs in some patients had been ascribed to the expansion of plasma volume (10). More recently it has been

\footnotetext{
1 Serum albumin used in this study was prepared by the American Red Cross from blood of volunteer donors. The conclusions are those of the authors and do not necessarily reflect the policy of the National Blood Program of the American Red Cross.

2 Aided by a grant from the James Hudson Brown Memorial Fund of the Yale University School of Medicine.

3 Work done in part while a Fellow of the Dazian Foundation for Medical Research, and during the tenure of a Life Insurance Medical Research Fellowship.

4 Work done during the tenure of a Postdoctorate Fellowship, U. S. Public Health Service.

5 Present adress: Stanford Medical School, San Francisco, California.
}

suggested that the intravenous injection of albumin increases the glomerular filtration rate and that this is associated with an enhanced flow of urine $(13,14)$. Gibson (14) postulates that sodium reabsorption may be interfered with by an increase in the filtration and reabsorption of protein.

With the view that the response of the kidneys is conditioned by the concentration and distribution of water and electrolytes within the body as well as local circulatory and osmotic effects, an attempt has been made to correlate shifts of water and electrolytes in the body with rate of excretion of these substances in the urine. Similarly, from observations of the sequence of events in the delivery of edema, information has been sought which might be applied to an analysis of edema in general.

By elevating the colloid osmotic pressure of the serum, intravenously injected albumin reverses the imbalance between oncotic and capillary pressures and draws interstitial fluid into the blood stream in hypoalbuminemia. The applicability of Starling's hypothesis to the explanation of the pathogenesis of some states of edema has been challenged recently $(10,14)$. Our data concerning changes in circulating protein and plasma volume will be analyzed with these objections in mind.

\section{EXPERIMENTAL MATERIAL AND PROCEDURE}

The seven patients studied included three with the nephrotic syndrome and three with toxemia of pregnancy. The data on one cirrhotic will be referred to briefly. All three patients with toxemia were in the last trimester of pregnancy. Albuminuria and edema were present in all and hypertension in two. Antecedent renal disease was excluded in each instance. One of the nephrotics (S. S.) was studied on two separate occasions. The data on two normal controls will appear in detail elsewhere. All of the subjects except E. H. and P. P. received $400 \mathrm{cc}$. of a 25 per cent solution of albumin intravenously. 
E. H. received $300 \mathrm{cc}$. and P. P. only $200 \mathrm{cc}$. Because of the gravity of their clinical condition, M. N., P. P., and E. H. were studied under somewhat modified circumstances. Since the time relationships in these studies differed greatly from that of the others, the data are not included in Figures 2 and 3. Others were deprived of food and water for at least eight hours before the experimental period. They remained in the recumbent position throughout the experiment and drank $100 \mathrm{cc}$. of water each hour. The studies were of six hours duration, divided into a two-hour control period, a two-hour period during which the infusion was administered and a final two-hour post-infusion period. Urines and bloods were obtained at the end of each period and in some instances at more frequent intervals.

\section{CHEMICAL METHODS AND CALCULATIONS}

The chemical methods and calculations used are those which have been previously described in publications from this department (15-18). Creatinine was determined by the method of Peters (19), urea by the urease method of Van Slyke (20). The initial chloride space was assumed to be 25 per cent of the body weight. Since changes in space were determined serially from one period to the next an incorrect assumption for the value of the initial space results in no appreciable error in the magnitude of the change. Recalculating the data, assuming an initial chloride space of 35 per cent in two patients did not alter the results significantly. Changes in plasma volume were estimated using the formula

$$
\frac{\mathrm{PV}_{2}}{\mathrm{PV}_{1}}=\frac{\mathrm{Hgb}_{1}}{\mathrm{Hgb}_{2}} \times \frac{1-\mathrm{Hkt}_{2}}{1-\mathrm{Hkt}_{1}}
$$

where $\mathrm{PV}_{1}$ equals an initial plasma volume of 100 per cent and $\mathrm{PV}_{2}$ the final plasma volume. $\mathrm{Hkt}_{1}$ and $\mathrm{Hkt}_{2}$ and $\mathrm{Hgb}_{1}$ and $\mathrm{Hgb}_{2}$ are the initial and final values of the relative red cell volume and concentration of hemoglobin respectively. The hemoglobin is included in the calcula-

TABLE I

The effect of albumin on serum proteins, and the volumes of plasma and urine

\begin{tabular}{|c|c|c|c|c|c|c|c|c|c|c|c|c|c|c|c|}
\hline $\begin{array}{l}\text { Patient and } \\
\text { Diagnosis }\end{array}$ & Period & $\begin{array}{l}\text { Dura- } \\
\text { tion }\end{array}$ & $\begin{array}{l}\text { Total } \\
\text { proteir }\end{array}$ & $\underset{\min }{\text { Albu- }}$ & $\begin{array}{c}\text { Globu- } \\
\text { lin }\end{array}$ & \begin{tabular}{|} 
Hemo- \\
globin
\end{tabular} & $\begin{array}{l}\text { Hema- } \\
\text { tocrit }\end{array}$ & $Q^{*}$ & $\frac{P V_{2 t}}{P V_{1}}$ & $\begin{array}{l}\text { Plasma } \\
\text { volume }\end{array}$ & $\begin{array}{c}\text { Total } \\
\text { circu- } \\
\text { lating } \\
\text { protein }\end{array}$ & $\begin{array}{c}\text { Total } \\
\text { circu- } \\
\text { lating } \\
\text { albumin }\end{array}$ & $\begin{array}{c}\text { Total } \\
\text { circu- } \\
\text { lating } \\
\text { globulin }\end{array}$ & $\begin{array}{c}\text { Intra- } \\
\text { venous } \\
\text { albumin }\end{array}$ & $\begin{array}{l}\text { Urine } \\
\text { flow }\end{array}$ \\
\hline \multirow{3}{*}{$\underset{\text { nephrosis }}{\text { S. S. } 1}$} & 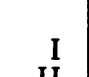 & min. & $\begin{array}{c}\text { gms. } \% \\
4.77\end{array}$ & $\begin{array}{l}\text { gms.\% } \\
1.64\end{array}$ & $\begin{array}{c}\text { gms. } \% \\
3.13\end{array}$ & \begin{tabular}{|l|} 
gms. $\%$ \\
14.3
\end{tabular} & $\begin{array}{c}\% \\
43.3\end{array}$ & 33.0 & $\begin{array}{c}\% \\
100\end{array}$ & $\begin{array}{l}\text { liters } \\
3.09\end{array}$ & $\begin{array}{l}\text { gms. } \\
147\end{array}$ & $\begin{array}{r}\text { gms. } \\
51\end{array}$ & $\begin{array}{r}\text { gms. } \\
96\end{array}$ & gms. & $\begin{array}{r}c c . / h r \\
82.0\end{array}$ \\
\hline & III & $\begin{array}{l}04 \\
54\end{array}$ & 5.89 & 3.64 & 2.25 & 10.2 & 30.5 & 33.4 & 172 & 5.31 & 31 & 193 & 120 & 50 & $\begin{array}{l}80.0 \\
35.6\end{array}$ \\
\hline & IV & 120 & 5.95 & 3.68 & 2. & 11.1 & 34.3 & 32.4 & 149 & & & 169 & 105 & 0 & 585.0 \\
\hline \multirow{4}{*}{$\begin{array}{r}\text { S. S. } 2 \\
\text { nephrosis }\end{array}$} & I & 120 & 4 & 1.54 & 2.99 & 13.3 & 43.1 & 30.8 & 100 & 3.10 & 141 & 48 & 93 & 0 & 95. \\
\hline & II & $\begin{array}{l}00 \\
60\end{array}$ & & 2 & 2 & 10.4 & 3 & 310 & 1 & 464 & 262 & 138 & 124 & 0 & \\
\hline & IV & 60 & 5.68 & & & & & & & & & 100 & & 0 & \\
\hline & V & 60 & 5.75 & 3.36 & 2.39 & 10.6 & 35.2 & 30.1 & 143 & 4.43 & 254 & 149 & 105 & 0 & 355.0 \\
\hline \multirow{4}{*}{$\begin{array}{c}\text { A. W. } \\
\text { nephrosis }\end{array}$} & I & 120 & & 1.37 & 3.67 & & 49.0 & .2 & 100 & & & & & 0 & 162 \\
\hline & II & 55 & & & & & 43.0 & & 122 & & & & & & \\
\hline & III & 62 & & 3.2 & 3.0 & 11.5 & 37.9 & 30.3 & 146 & 6. & & & & 50 & 324.0 \\
\hline & IV & $\mid 126$ & & 2.86 & 2.88 & 11.5 & 36.5 & 31.5 & 149 & 6. & & 18 & & 0 & 389.4 \\
\hline \multirow{3}{*}{$\begin{array}{c}\text { M. N. } \\
\text { nephrosis }\end{array}$} & & 118 & 4 & 81 & 3.75 & 13.4 & 40.0 & 33.5 & 100 & 3. & & $2 \varepsilon$ & & 0 & 15 \\
\hline & I & & & & & 9.8 & 291 & & 161 & & & & & 50 & \\
\hline & IV & & & & & 8.9 & $\begin{array}{l}25.0 \\
25.4\end{array}$ & .0 & $\begin{array}{l}191 \\
187\end{array}$ & & & & & o & 131.0 \\
\hline \multirow{4}{*}{$\begin{array}{l}\text { F. J. } \\
\text { toxemia of } \\
\text { pregnancy }\end{array}$} & & & & & & & 07 & & & & & & & & \\
\hline & II & 58 & & & 2 & & 32.3 & 30.9 & 133 & & & & & 50 & 78 \\
\hline & III & 61 & 6. & 4.07 & 2.4 & 10.4 & 33.8 & 30.8 & 125 & 5. & & & & 50 & 624 \\
\hline & IV & 120 & & & & 16 & 35 & 29.8 & 117 & & 30 & & & 0 & 287 \\
\hline \multirow{3}{*}{$\begin{array}{l}\text { P. C. } \\
\text { toxemia of } \\
\text { pregnancy }\end{array}$} & II & $\begin{array}{r}120 \\
60\end{array}$ & 5.53 & 2.88 & 2.65 & 9.6 & 35.0 & 27.4 & 100 & 3.82 & 21 & 110 & 10 & $\begin{array}{r}0 \\
50\end{array}$ & 92.5 \\
\hline & III & 60 & 6. & 3.88 & 2.38 & 7.2 & 26.4 & 27.3 & 151 & 5 & 36 & 2 & 1 & 50 & 225 \\
\hline & IV & 120 & & & & 7.8 & & 28.9 & 138 & & & & & 0 & 260.0 \\
\hline \multirow{4}{*}{$\begin{array}{l}\text { E. H. } \\
\text { toxemia of } \\
\text { pregnancy }\end{array}$} & & & & & & & & & & & & & & & \\
\hline & II & 125 & 7.03 & & 2.99 & 5.6 & 33.3 & 16.8 & 155 & & 37 & 21 & 15 & 75 & 116.3 \\
\hline & IV & $\begin{array}{r}56 \\
296\end{array}$ & & & $\begin{array}{l}2.74 \\
2.70\end{array}$ & $\begin{array}{l}5.8 \\
5.8\end{array}$ & $\begin{array}{l}33.1 \\
34.1\end{array}$ & $\begin{array}{l}17.5 \\
17.1\end{array}$ & $\begin{array}{l}150 \\
147\end{array}$ & & & $\begin{array}{l}19 \\
18\end{array}$ & & $\begin{array}{l}0 \\
0\end{array}$ & $\begin{array}{l}208.5 \\
123.6\end{array}$ \\
\hline & & & & & & & & & & & & & & & \\
\hline
\end{tabular}

* Hemoglobin as grams per 100 cc. red blood cells.

$\dagger$ Per cent change in plasma volume-initial plasma volume equal to 100 per cent.

S. S. 1 and S. S. 2 refer to separate studies on the same patient. 
tion to correct for any changes in the volume of red blood cells which might occur when the concentration of electrolytes in the serum changes. Water of serum was calculated from the formula $\mathrm{W}_{\mathrm{s}}=98.4-0.718 \mathrm{P}$, where W. equals the amount of water in $100 \mathrm{cc}$. of serum and $P$ the concentration of total protein in grams per cent (21). Changes in body water were calculated from changes in body weight when available, and at other times from the balance of water. Changes in intracellular water $(\Delta \mathrm{I})$ were obtained by means of two different formulae: 1) $\Delta \mathrm{I}=\Delta \mathrm{W}-\Delta \mathrm{E}$, where $\mathrm{W}$ equals body water and $\mathrm{E}$ extracellular volume as measured by the chloride space. 2) $\Delta \mathrm{I}=\mathrm{b} \mathrm{H}_{2} \mathrm{O}-\Delta \mathrm{E}$, where b $\mathrm{H}_{2} \mathrm{O}$ refers to the balance of water. This figure was obtained by subtracting the sum of the urine volume and an arbitrary figure of $20 \mathrm{cc}$. per hour representing the composite of insensible water loss, water of oxidation, and the water in the samples of blood analyzed, from the total intake of water. The water in $400 \mathrm{cc}$. of 25 per cent albumin was assumed to be $325 \mathrm{cc}$. Colloid osmotic pressure was calculated by assuming that each gram of albumin was equivalent to $5.5 \mathrm{~mm}$. of $\mathrm{Hg}$ and each gram of globulin to $1.4 \mathrm{~mm}$. of $\mathrm{Hg}$ (22). Admittedly, this is only a gross approximation in view of the changes in the method of plasma fractionation introduced since these figures were derived.

\section{RESULTS}

Primary and derived data are presented in Tables I to IV. Individual experiments are illustrated in Figures 5 and 6, with composite graphs of the results in Figures 1 to 3 .

Changes in serum proteins and plasma volume. The data relating to the changes in total circulating protein and their concentrations are repre-

TABLE II

The effect of albumin on colloid osmotic pressure

\begin{tabular}{|c|c|c|c|c|c|c|}
\hline \multirow{2}{*}{ Patient } & \multirow{2}{*}{$\begin{array}{c}\text { Intra- } \\
\text { venous } \\
\text { albumin }\end{array}$} & \multicolumn{4}{|c|}{ Increase in } & \multirow{2}{*}{$\begin{array}{l}\begin{array}{c}\text { Number } \\
\text { of } \\
\text { “cc. H2O" }\end{array} \\
\begin{array}{c}\text { per gram } \\
\text { albumin }\end{array}\end{array}$} \\
\hline & & $\frac{\mathrm{PV}_{2^{*}}}{\mathrm{PV}_{1}}$ & $\begin{array}{l}\text { Circu- } \\
\text { lating } \\
\text { albumin }\end{array}$ & $\begin{array}{c}\text { Circu- } \\
\text { lating } \\
\text { globulin }\end{array}$ & $\begin{array}{l}\text { Colloid† } \\
\text { osmotic } \\
\text { pressure }\end{array}$ & \\
\hline $\begin{array}{l}\text { S. S.1 } \\
\text { S. S. } \\
\text { A. W. W. } \\
\text { M. N. } \\
\text { F. J. } \\
\text { P. C. } \\
\text { E. H. }\end{array}$ & $\begin{array}{r}\text { gms. } \\
100 \\
100 \\
100 \\
100 \\
100 \\
100 \\
75\end{array}$ & $\begin{array}{l}72 \\
50 \\
46 \\
91 \\
25 \\
51 \\
55\end{array}$ & $\begin{array}{r}\text { gms. } \\
142 \\
90 \\
145 \\
193 \\
100 \\
114 \\
132\end{array}$ & $\begin{array}{c}\text { gms. } \\
24 \\
31 \\
34 \\
28 \\
14 \\
36 \\
39\end{array}$ & $\begin{array}{c}m m . H g \\
9.7 \\
7.4 \\
9.2 \\
9.6 \\
7.3 \\
6.2 \\
8.2\end{array}$ & $\begin{array}{l}22.2 \\
15.4 \\
20.3 \\
31.6 \\
10.4 \\
19.4 \\
25.1\end{array}$ \\
\hline & & & & & 8 & 20.6 \\
\hline
\end{tabular}

* Percentage increase in plasma volume.

$\dagger$ Calculated on the hypothesis that each gram of albumin equals $5.5 \mathrm{~mm} . \mathrm{Hg}$ and each gram of globulin 1.4 $\mathrm{mm} . \mathrm{Hg}$

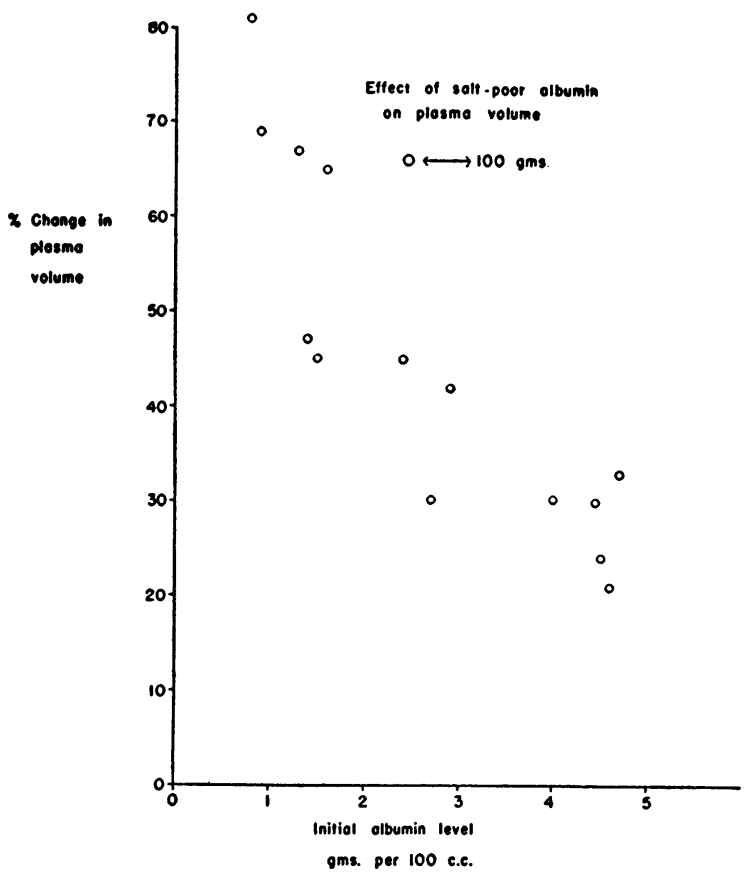

Fig. 1. The Relationship Between the Initial Concentration of Serum Albumin and the Percentage Rise in Plasma when 100 Grams of Albumin Were Infused in Patients and in Normal Controls

sented in Table I. In every instance, irrespective of the magnitude of the associated diuresis, both the concentration and total amount of circulating protein rose considerably and remained elevated above the initial value throughout the entire period of study. However, only if the diuresis during the last two hours was great enough to induce a fairly rapid fall in plasma volume did the concentration of protein continue to rise after the completion of the infusion of albumin. The serum albumin changed similarly while the concentration of globulin fell in a reciprocal fashion probably as a result of the expansion of plasma volume and consequent hemodilution.

The increases in plasma volume (Table I) were quite variable. From this and other unpublished data it is clear that the magnitude of the increase in a given subject was unrelated to the dose of albumin when either 75 or 100 grams were infused (23). In some instances the percentage increase was nearly maximal after only half of the albumin had been injected. The increase in plasma volume and the change in concentration of protein were related both to the magnitude and to the time of the resultant diuresis. The greater the diuresis, 
TABLE III

Summary of data on the clearances of creatinine and urea, excretion of electrolytes and water, and concentration of extracellular electrolytes

\begin{tabular}{|c|c|c|c|c|c|c|c|c|c|c|c|c|c|}
\hline \multirow{2}{*}{ Patient } & \multirow{2}{*}{ Period } & \multirow{2}{*}{ Duration } & \multicolumn{2}{|c|}{ Extracell. $\mathrm{H}_{2} \mathrm{O}^{*}$} & \multirow{2}{*}{$\underset{\mathbf{K}}{\text { Serum }}$} & \multirow{2}{*}{$\begin{array}{l}\text { Blood } \\
\text { NPN }\end{array}$} & \multicolumn{5}{|c|}{ Rates of excretion in urine } & \multicolumn{2}{|c|}{ Clearances } \\
\hline & & & $\mathrm{Na}$ & $\mathrm{Cl}$ & & & $\mathbf{N a}$ & $\mathrm{Cl}$ & $\mathbf{K}$ & $\mathrm{H}_{2} \mathrm{O}$ & Protein & Creatininet & Urea \\
\hline S. S. 1 & $\begin{array}{l}\text { I } \\
\text { II } \\
\text { III } \\
\text { IV }\end{array}$ & $\begin{array}{r}\min . \\
125 \\
64 \\
54 \\
120\end{array}$ & $\begin{array}{l}\text { meq/L. } \\
140.5 \\
144.0 \\
146.7\end{array}$ & $\begin{array}{c}\text { meq/L. } \\
111.1 \\
112.2 \\
115.5\end{array}$ & $\begin{array}{c}m e q / L . \\
4.4 \\
3.9 \\
3.9\end{array}$ & $\begin{array}{c}\text { mgm.\% } \\
36 \\
35 \\
33\end{array}$ & $\begin{array}{r}\text { meq/hr. } \\
0.40 \\
1.00 \\
2.86 \\
20.90\end{array}$ & $\begin{array}{r}\text { meq/hr. } \\
0.59 \\
1.46 \\
2.67 \\
18.60\end{array}$ & $\begin{array}{r}\text { meq } / \mathrm{hr} . \\
3.44 \\
3.71 \\
8.95 \\
6.90\end{array}$ & $\begin{array}{r}c c . / h r . \\
82.0 \\
80.0 \\
35.6 \\
585.0\end{array}$ & $\begin{array}{c}\text { gms./hr. } \\
0.81 \\
0.73 \\
2.42 \\
1.68\end{array}$ & $\left.\begin{array}{c}c c . / \min . \\
71.8 \\
48.5 \\
103.6 \\
72.8\end{array}\right\}$ & \begin{tabular}{|c}
$c c . / \min$. \\
51.6 \\
72.2 \\
43.4 \\
50.2
\end{tabular} \\
\hline S. S. 2 & $\begin{array}{l}\text { I } \\
\text { II } \\
\text { III } \\
\text { IV } \\
\text { V }\end{array}$ & $\begin{array}{r}120 \\
60 \\
60 \\
60 \\
60\end{array}$ & $\begin{array}{l}138.3 \\
139.5 \\
139.1 \\
144.0 \\
144.9\end{array}$ & $\begin{array}{l}119.5 \\
119.1 \\
119.2 \\
122.5 \\
121.4\end{array}$ & $\begin{array}{l}4.4 \\
4.0 \\
4.0\end{array}$ & $\begin{array}{l}37 \\
36 \\
38 \\
34 \\
36\end{array}$ & $\begin{array}{r}0.40 \\
1.39 \\
7.46 \\
24.60 \\
26.20\end{array}$ & $\begin{array}{r}2.31 \\
3.32 \\
6.90 \\
21.20 \\
25.60\end{array}$ & $\begin{array}{l}4.50 \\
6.50 \\
6.63 \\
5.95 \\
6.00\end{array}$ & $\begin{array}{r}95.0 \\
145.0 \\
460.0 \\
815.0 \\
355.0\end{array}$ & & & \\
\hline A. $W$. & $\begin{array}{l}\text { I } \\
\text { II } \\
\text { III } \\
\text { IV }\end{array}$ & $\begin{array}{r}120 \\
55 \\
62 \\
126\end{array}$ & $\begin{array}{l}138.9 \\
143.6 \ddagger \\
143.0 \\
144.9\end{array}$ & $\begin{array}{l}112.1 \\
112.8 \\
114.0 \\
118.6\end{array}$ & $\begin{array}{l}5.2 \\
4.8 \\
5.0 \\
4.3\end{array}$ & $\begin{array}{l}32 \\
31 \\
33 \\
30\end{array}$ & $\begin{array}{l}3.43 \\
4.25 \\
6.06 \\
9.46\end{array}$ & $\begin{array}{l}5.50 \\
5.24 \\
3.76 \\
8.46\end{array}$ & $\begin{array}{l}3.96 \\
5.44 \\
5.19 \\
4.04\end{array}$ & $\begin{array}{l}162.5 \\
157.8 \\
324.0 \\
389.4\end{array}$ & $\begin{array}{l}0.23 \\
0.56 \\
0.50 \\
0.71\end{array}$ & $\begin{array}{r}88.0 \\
94.0 \\
100.6 \\
94.5\end{array}$ & $\begin{array}{l}46.4 \\
48.5 \\
48.0 \\
47.3\end{array}$ \\
\hline M. N. & $\begin{array}{l}\text { I } \\
\text { II } \\
\text { III } \\
\text { IV }\end{array}$ & $\begin{array}{l}118 \\
115 \\
130 \\
119\end{array}$ & $\begin{array}{l}139.5 \\
138.9 \\
140.2 \\
143.7\end{array}$ & $\begin{array}{l}121.8 \\
121.2 \\
123.8 \\
124.5\end{array}$ & $\begin{array}{l}3.8 \\
3.3 \\
3.4 \\
2.8\end{array}$ & $\begin{array}{l}41 \\
35 \\
36 \\
47\end{array}$ & $\begin{array}{l}2.76 \\
3.76 \\
9.80 \\
7.17\end{array}$ & $\begin{array}{l}3.70 \\
2.96 \\
7.99 \\
6.44\end{array}$ & $\begin{array}{l}2.78 \\
2.56 \\
2.77 \\
1.60\end{array}$ & $\begin{array}{l}158.0 \\
229.0 \\
295.0 \\
131.0\end{array}$ & $\begin{array}{l}0.53 \\
0.53 \\
1.14 \\
1.03\end{array}$ & $\begin{array}{l}44.2 \\
41.6 \\
43.1 \\
26.2\end{array}$ & $\begin{array}{l}23.3 \\
22.5 \\
21.5 \\
14.5\end{array}$ \\
\hline F. J. & $\begin{array}{l}\text { I } \\
\text { II } \\
\text { III } \\
\text { IV }\end{array}$ & $\begin{array}{r}117 \\
58 \\
61 \\
120\end{array}$ & $\begin{array}{l}137.5 \\
137.2 \\
143.0 \\
143.5\end{array}$ & $\begin{array}{l}114.1 \\
114.5 \\
115.1 \\
116.2\end{array}$ & $\begin{array}{l}3.7 \\
3.5 \\
3.4 \\
3.6\end{array}$ & $\begin{array}{l}23 \\
19 \\
20 \\
20\end{array}$ & $\begin{array}{r}2.74 \\
4.08 \\
7.18 \\
16.35\end{array}$ & $\begin{array}{r}3.83 \\
3.58 \\
5.54 \\
15.60\end{array}$ & $\begin{array}{l}0.35 \\
0.82 \\
1.62 \\
1.79\end{array}$ & $\begin{array}{r}37.2 \\
78.6 \\
624.0 \\
287.5\end{array}$ & & $\begin{array}{r}91.0 \\
118.4 \\
104.0 \\
99.5\end{array}$ & $\begin{array}{l}31.2 \\
47.9 \\
41.1 \\
33.8\end{array}$ \\
\hline P. C. & $\begin{array}{l}\text { I } \\
\text { III } \\
\text { IV }\end{array}$ & $\begin{array}{r}120 \\
60 \\
60 \\
120\end{array}$ & $\begin{array}{l}139.4 \\
139.8 \\
138.6\end{array}$ & $\begin{array}{l}113.7 \\
114.9 \\
114.1\end{array}$ & $\begin{array}{l}4.4 \\
\\
4.4 \\
4.4\end{array}$ & $\begin{array}{l}30 \\
26 \\
28\end{array}$ & $\begin{array}{r}10.72 \\
5.10 \\
12.40 \\
7.70\end{array}$ & $\begin{array}{r}12.72 \\
5.50 \\
10.22 \\
5.64\end{array}$ & $\begin{array}{l}4.00 \\
1.00 \\
5.40 \\
2.70\end{array}$ & $\begin{array}{r}92.5 \\
39.0 \\
225.0 \\
260.0\end{array}$ & & $\left.\begin{array}{c}99.0 \\
39.7 \\
131.0 \\
82.0\end{array}\right\}$ & $\left.\begin{array}{l}54.2 \\
25.0 \\
80.2 \\
41.3\end{array}\right\}$ \\
\hline E. H. & $\begin{array}{l}\text { I } \\
\text { III } \\
\text { IV }\end{array}$ & $\begin{array}{r}60 \\
125 \\
56 \\
296\end{array}$ & $\begin{array}{l}133.7 \\
132.5 \\
136.6 \\
136.7\end{array}$ & $\begin{array}{l}112.6 \\
113.8 \\
115.1 \\
112.2\end{array}$ & & $\begin{array}{l}34 \\
31 \\
35 \\
33\end{array}$ & $\begin{array}{l}0.74 \\
1.04 \\
0.67 \\
0.92\end{array}$ & $\begin{array}{l}1.03 \\
1.06 \\
1.10 \\
0.69\end{array}$ & & $\begin{array}{r}63.6 \\
116.3 \\
208.5 \\
123.6\end{array}$ & $\begin{array}{l}0.73 \\
0.19 \\
0.38 \\
0.30\end{array}$ & $\begin{array}{l}44.6 \\
59.0 \\
75.5 \\
54.3\end{array}$ & $\begin{array}{l}14.9 \\
20.3 \\
25.7 \\
15.6\end{array}$ \\
\hline P. P. & $\begin{array}{r}\text { I } \\
\text { II } \\
\text { III } \\
\text { IV } \\
\text { V }\end{array}$ & $\begin{array}{l}\mathbf{5 5} \\
70 \\
55 \\
60 \\
55\end{array}$ & & $\begin{array}{l}110.0 \\
110.0 \\
110.2 \\
109.7 \\
110.9\end{array}$ & & & $\begin{array}{l}3.87 \\
4.62 \\
5.24 \\
6.24 \\
5.01\end{array}$ & $\begin{array}{r}4.63 \\
4.60 \\
3.55 \\
13.89 \\
5.55\end{array}$ & & $\begin{array}{l}106.8 \\
240.0 \\
399.6 \\
382.0 \\
300.0\end{array}$ & & $\begin{array}{l}69.0 \\
65.0 \\
66.0 \\
78.5 \\
78.1\end{array}$ & $\begin{array}{l}48.6 \\
65.8 \\
64.7 \\
74.4 \\
34.9\end{array}$ \\
\hline
\end{tabular}

* Corrected for Donnan factor.

t Endogenous creatinine.

$\ddagger$ May be analytical error since no rise in chloride.

$\$$ When both periods combined $=74$ cc. per minute (creatinine)

$=53 \mathrm{cc}$. per minute (urea).

II When both periods combined

$=85.2 \mathrm{cc}$. per minute (creatinine)

$=53.6 \mathrm{cc}$. per minute (urea).

the smaller the increase in plasma volume and the greater the rise in concentration of albumin.

The percentage increase in plasma volume was greatest (Figure 1) in those subjects whose initial concentration of albumin was lowest. These figures were obtained from unpublished studies of other patients and of normal individuals as well as from the series of patients here reported.
In general, more albumin than was infused was accounted for in the serum by calculation (Table II). The formula employed for the calculation of changes in plasma volume is probably valid in short-term experiments. It has been claimed that the use of venous blood for the determination of the hematocrit may give larger values for plasma volume than other more precise methods (24). 
This, together with the error inherent in assuming an arbitrary value for the original plasma volume, explains the high recoveries of circulating protein. However, with respect to globulin, Luetscher (2) had previously reported a similar finding and it is not inconceivable that such an increase might occur if the flow of lymph were augmented by the infusion.

Despite the variability in individal results as well as the probable error in the calculations of plasma volume, the number of cubic centimeters of fluid drawn into the vascular tree by each gram of albumin averaged $20.6 \mathrm{cc}$. (Table II). This is in fair agreement with other reports in the literature of the osmotic efficiency of albumin $(25,26)$.
There was no significant change in the size of the red cells (Table I) since the amount of hemoglobin in $100 \mathrm{cc}$. of red blood cells did not change.

Effect on proteinuria. Most observers have noted uniform increases in preexisting albuminuria in nephrotics following the infusion of albu$\min (3,4,6)$. Waterhouse, Bassett, and Holler (27), induced marked albuminuria after four days of infusion in a patient who had had only occasional mild proteinuria. An increase in the excretion of protein occurred in all three of our nephrotics (Table III). E. H., however, not only had less proteinuria on the day of the infusion of albumin than previously, but actually excreted less albumin during the two hours of the infusion than

TABLE IV

Exchanges of water and electrolytes as influenced by albumin

\begin{tabular}{|c|c|c|c|c|c|c|c|c|c|c|c|c|c|}
\hline \multirow{3}{*}{ Patient } & \multirow{3}{*}{ Period } & \multirow{3}{*}{$\begin{array}{c}\text { Dura- } \\
\text { tion }\end{array}$} & \multirow{2}{*}{\multicolumn{3}{|c|}{ External balance* }} & \multirow{3}{*}{$\begin{array}{l}\text { Extra- } \\
\text { cellular } \\
\text { volumet }\end{array}$} & \multicolumn{7}{|c|}{ Changes in } \\
\hline & & & & & & & \multirow{2}{*}{$\begin{array}{l}\text { Total } \\
\text { body } \\
\text { water }\end{array}$} & \multirow{2}{*}{$\begin{array}{l}\text { Intra- } \\
\text { cellular } \\
\text { water }\end{array}$} & \multirow{2}{*}{$\begin{array}{l}\text { Intra- } \\
\text { cellular } \\
\text { water|| }\end{array}$} & \multicolumn{2}{|c|}{ Extracellular } & \multicolumn{2}{|c|}{ Cellular } \\
\hline & & & $\mathrm{Na}$ & $\mathrm{Cl}$ & $\mathrm{K}$ & & & & & $\mathrm{Na}$ & $\mathbf{K}$ & $\mathrm{Na}$ & $\mathrm{K}$ \\
\hline S. S. 1 & $\begin{array}{l}\text { I } \\
\text { II } \\
\text { III } \\
\text { IV }\end{array}$ & $\left.\begin{array}{c}\min . \\
125 \\
64 \\
54 \\
120\end{array}\right\}$ & $\begin{array}{c}\text { meq } \\
-4.33 \\
+55.67 \\
-45.30\end{array}$ & $\begin{array}{c}\text { meq } \\
-3.72 \\
+\quad 1.54 \\
-39.70\end{array}$ & $\begin{array}{c}\text { meq } \\
-7.16 \\
-12.02 \\
-13.80\end{array}$ & $\begin{array}{c}\text { liters } \\
(15.45) \\
15.34 \\
14.58\end{array}$ & -0.91 & -0.15 & -0.04 & $\begin{array}{c}\text { meq } / \mathrm{hr} . \\
0 \\
+13.21 \\
-40.50\end{array}$ & $\begin{array}{c}\text { meq/hr. } \\
0 \\
-4.17 \\
-1.50\end{array}$ & $\begin{array}{l}\text { meq/hr. } \\
-2.08 \\
+15.10 \\
+17.85\end{array}$ & $\begin{array}{l}\text { meq/hr. } \\
-3.44 \\
-1.94 \\
-5.40\end{array}$ \\
\hline S. S. 2 & $\begin{array}{l}\text { I } \\
\text { II } \\
\text { III } \\
\text { IV } \\
\text { V }\end{array}$ & $\begin{array}{r}120 \\
60 \\
60 \\
60 \\
60\end{array}$ & $\begin{array}{r}-4.30 \\
+26.50 \\
+20.40 \\
-28.10 \\
-29.70\end{array}$ & $\begin{array}{r}7.30 \\
-\quad 2.00 \\
-\quad 5.60 \\
-23.90 \\
-28.30\end{array}$ & $\begin{array}{l}-9.00 \\
-6.50 \\
-6.60 \\
-\quad 5.90 \\
-6.00\end{array}$ & $\begin{array}{c}(15.50) \\
15.54 \\
15.46 \\
14.90 \\
14.76\end{array}$ & -0.91 & -0.55 & -0.17 & $\begin{array}{c}0 \\
+24.00 \\
+18.00 \\
-7.00 \\
-4.00\end{array}$ & $\begin{array}{l}0 \\
+\quad 0.20 \\
-\quad 6.50 \\
+\quad 2.30 \\
-\quad 0.50\end{array}$ & $\begin{array}{r}-2.15 \\
+\quad 2.50 \\
+38.40 \\
-21.10 \\
-25.70\end{array}$ & $\begin{array}{l}-4.50 \\
-6.70 \\
-0.10 \\
-8.20 \\
-5.50\end{array}$ \\
\hline A. $W$. & $\begin{array}{l}\text { I } \\
\text { II } \\
\text { III } \\
\text { IV }\end{array}$ & $\begin{array}{r}120 \\
55 \\
62 \\
126\end{array}$ & $\begin{array}{l}-10.36 \\
+24.00 \\
+21.65 \\
-23.40\end{array}$ & $\begin{array}{r}-13.50 \\
-3.30 \\
-2.39 \\
-20.25\end{array}$ & $\begin{array}{l}-7.92 \\
-\quad 4.99 \\
-5.36 \\
-8.50\end{array}$ & $\begin{array}{c}(22.00) \\
21.90 \\
21.60 \\
20.50\end{array}$ & -1.70 & +0.58 & -0.20 & $\begin{array}{c}0 \\
+92.70 \\
-48.40 \\
-57.10\end{array}$ & $\begin{array}{c}0 \\
-10.15 \\
+\quad 2.91 \\
-\quad 9.43\end{array}$ & $\begin{array}{r}-5.18 \\
-66.60 \\
+69.40 \\
+46.00\end{array}$ & $\begin{array}{l}-3.96 \\
+4.59 \\
-8.10 \\
+5.38\end{array}$ \\
\hline M. N. & $\begin{array}{l}\text { I } \\
\text { II } \\
\text { III } \\
\text { IV }\end{array}$ & $\begin{array}{l}118 \\
115 \\
130 \\
119\end{array}$ & $\begin{array}{r}-8.94 \\
+20.69 \\
+\quad 6.70 \\
-17.70\end{array}$ & $\begin{array}{r}-10.08 \\
-4.47 \\
-16.10 \\
-15.60\end{array}$ & $\begin{array}{l}-5.46 \\
-4.91 \\
-6.00 \\
-3.17\end{array}$ & $\begin{array}{c}(17.40) \\
17.41 \\
16.95 \\
16.74\end{array}$ & & -0.25 & & $\begin{array}{c}0 \\
-3.64 \\
-18.00 \\
+12.60\end{array}$ & $\begin{array}{l}0 \\
-\quad 4.48 \\
+\quad 0.92 \\
-\quad 5.44\end{array}$ & $\begin{array}{r}-4.65 \\
+14.40 \\
+21.10 \\
-21.50\end{array}$ & $\begin{array}{l}-2.78 \\
+1.92 \\
-2.86 \\
+3.84\end{array}$ \\
\hline F. J. & $\begin{array}{l}\text { I } \\
\text { II } \\
\text { III } \\
\text { IV }\end{array}$ & $\begin{array}{r}117 \\
58 \\
61 \\
120\end{array}$ & $\begin{array}{r}-8.84 \\
+23.46 \\
+20.59 \\
-36.20\end{array}$ & $\begin{array}{r}-10.09 \\
-\quad 2.06 \\
-4.23 \\
-33.82\end{array}$ & $\begin{array}{r}-0.18 \\
-0.79 \\
-\quad 1.65 \\
-\quad 3.58\end{array}$ & $\begin{array}{c}(21.00) \\
20.88 \\
20.69 \\
20.30\end{array}$ & -0.91 & +0.46 & -0.21 & $\begin{array}{c}0 \\
-20.70 \\
+88.60 \\
-22.50\end{array}$ & $\begin{array}{ll} & 0 \\
- & 4.45 \\
- & 2.86 \\
+ & 1.35\end{array}$ & $\begin{array}{l}-4.53 \\
+45.00 \\
-68.40 \\
-4.40\end{array}$ & $\begin{array}{l}-0.95 \\
+3.63 \\
+1.23 \\
-3.14\end{array}$ \\
\hline P. C. & $\begin{array}{c}\text { I } \\
\text { II } \\
\text { III } \\
\text { IV }\end{array}$ & $\left.\begin{array}{c}120 \\
60 \\
60 \\
120\end{array}\right\}$ & $\begin{array}{r}-24.90 \\
+41.70 \\
-18.90\end{array}$ & $\begin{array}{l}-27.94 \\
-10.22 \\
-13.78\end{array}$ & $\begin{array}{l}-8.00 \\
-\quad 1.00 \\
-5.40 \\
-\quad 5.40 \\
\end{array}$ & $\begin{array}{c}(19.10) \\
\\
18.85 \\
18.85 \\
\end{array}$ & -0.20 & +0.01 & +0.05 & $\begin{array}{c}0 \\
-15.00 \\
-12.50 \\
\end{array}$ & $\begin{array}{l}0 \\
-\quad \begin{array}{l}0.50 \\
0\end{array} \\
\end{array}$ & $\begin{array}{r}-12.49 \\
+35.85 \\
+\quad 3.05 \\
\end{array}$ & $\begin{array}{l}-4.00 \\
-2.70 \\
-2.70 \\
\end{array}$ \\
\hline E. H. & $\begin{array}{l}\text { I } \\
\text { II } \\
\text { III } \\
\text { IV }\end{array}$ & $\begin{array}{r}60 \\
125 \\
56 \\
296\end{array}$ & $\begin{array}{r}-4.14 \\
+42.54 \\
-4.03 \\
-7.94\end{array}$ & $\begin{array}{r}-3.53 \\
+1.30 \\
-3.53 \\
-5.81\end{array}$ & & $\begin{array}{c}(17.20) \\
17.05 \\
16.80 \\
17.15\end{array}$ & -0.35 & +0.12 & -0.30 & $\begin{array}{c}0 \\
-19.20 \\
+37.50 \\
+9.12\end{array}$ & & $\begin{array}{r}4.14 \\
+39.60 \\
+33.10 \\
-10.70\end{array}$ & \\
\hline
\end{tabular}

* Balances of $\mathrm{Na}$ and $\mathrm{Cl}$ corrected for small quantities removed in serum drawn for analysis.

$\dagger$ Calculated forward in individual period af ter an assumed initial volume designated by parenthesis.

$\neq$ Calculated from water balance and change in extracellular volume.

II Calculated from changes in weight and extracellular volume. 


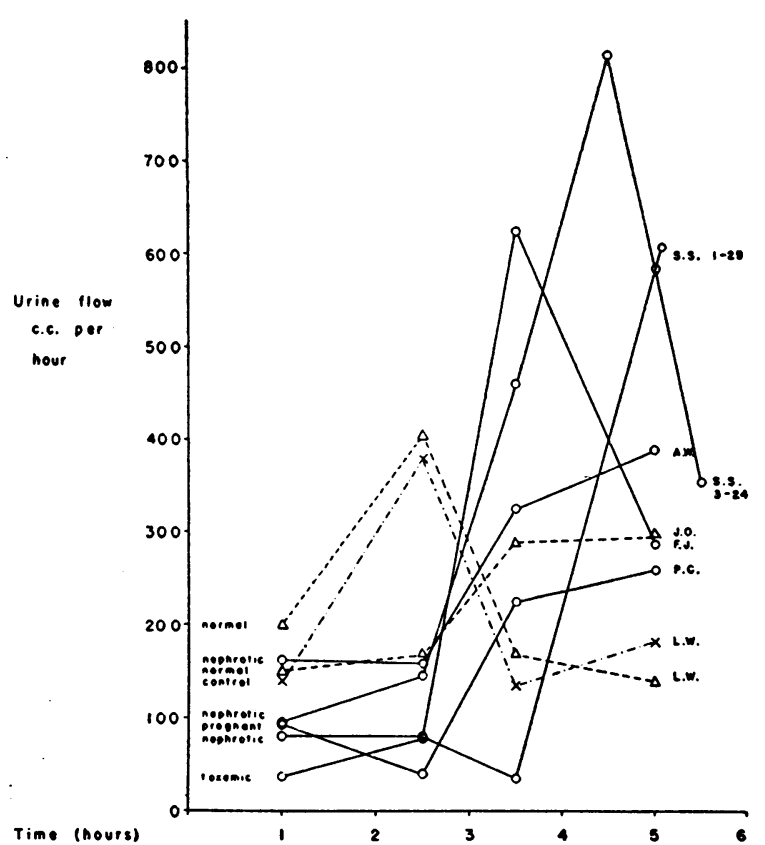

Belenee period $1 \longmapsto$ control $\longrightarrow \mid \leqslant 100$ gms. olbumin $\rightarrow \mid+$ post infusion $\rightarrow 1$

Fig. 2. Changes in Urine Flow Induced by the Intravenous Injection of Albumin

The patient referred to as "pregnant" had a mild toxemia of pregnancy. The control received $325 \mathrm{cc}$. of water containing the same amount of sodium as is present in 100 grams of albumin.

during the preceding control period. The other two patients with toxemia of pregnancy retained all of the albumin though they had had intermittent proteinuria previously. In the nephrotics the extent of the augmented proteinuria was proportional only to the concentration of albumin in the serum. This had been reported by Eder (4), although Luetscher (2) found no significant changes in clearances of albumin. There was no correlation with either salt or water excretion or with clearances of creatinine or urea.

Shifts of water and electrolytes (Table IV). Extracellular volume as measured by chloride space contracted on the five occasions when clearcut diuresis supervened. Though intracellular shifts of water were calculated both from changes in weight and from balances of water, none of these changes were significant. However, since the rise in concentration of sodium in the extracellular water appears to be a result of the contraction of extracellular space consequent to the excretion of water in excess of sodium, water must have moved from the cells to the extracellular space to maintain osmotic equilibrium, unless there had occurred, independently and simultaneously, an increase in osmolarity within the cells.

Cellular exchanges of sodium and potassium were neither consistently in the same direction nor of great enough magnitude to permit interpretation.

Excretion of water. These data are presented in Table III and Figure 2. There was a distinct rise in the hourly excretion of water beginning in the second hour of the infusion in all of the cases studied in this manner. Evaluation is difficult in E. H. and P. P. since their oral intake of water exceeded that of the others, while the changes in rate of water excretion in $\mathrm{P}$. C. were even less than in a normal control, J. O. L. W., another normal, excreted no more urine when given 25 per cent albumin intravenously than when given $325 \mathrm{cc}$. of water with the same amount of sodium as is present in concentrated salt-poor albumin.

Excretion of sodium and potassium. Whatever the fundamental physiological imbalance is in edematous patients an altered ability to excrete sodium is common to most of them.. Water retention generally appears to be a secondary phe-

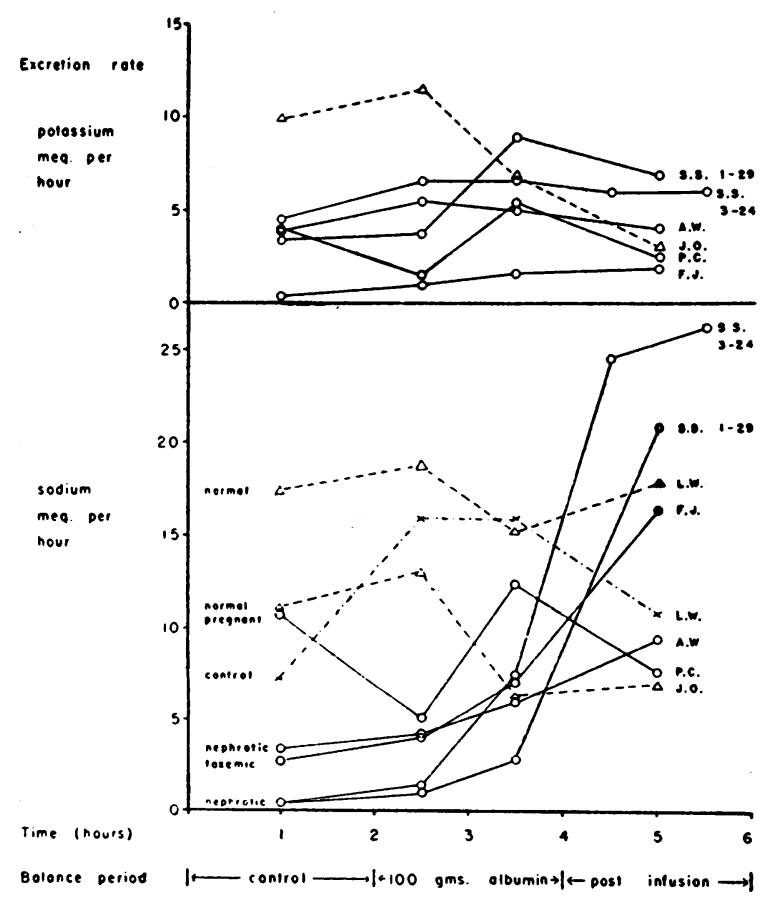

Fig. 3. Changes in the Rates of Excretion of Potassium and Sodium Induced by the Intravenous Injection of Albumin 
nomenon and is usually overcome if a means of decreasing tubular reabsorption of sodium is achieved. It has been mentioned above that normal individuals (Figure 3 ) respond to an infusion of concentrated human albumin by reducing their rate of excretion of sodium. This does not occur if $325 \mathrm{cc}$. of water containing 157 milliequivalents per liter of sodium, equivalent to the amount in 100 grams of albumin is infused. In direct contrast in all of the patients with nephrosis and one of the three with toxemia of pregnancy the rate of the excretion of salt increased when albumin was administered. In each one of the patients in whom salt excretion increased the concentration of sodium in the extracellular water first rose. In not one of either the normal controls or the three patients who had no change in salt excretion did the concentration of serum sodium rise.

There was no clear-cut consistency in the changes of potassium in these experiments. Table III and Figure 3 illustrate that perhaps there was a relative increase in the excretion of this cation when compared with the excretion of potassium by a normal control. The changes in the concentration of serum potassium were small and most often within the limits of error of the method. Gamble noted no significant changes either in the 24-hour excretion of potassium or in its concentration in the serum except in one patient 20 hours after an infusion of albumin (26).

Clearances of endogenous creatinine and urea. The date pertaining to clearances are in Table III. Endogenous creatinine and urea clearances were measured in order not to introduce any exogenous agents which might, in themselves, alter the phenomena under investigation. Admittedly, they will not provide quantitative measurements of glomerular filtration, but they should at least reveal directional changes in this function. Since none of the subjects were catheterized changes of less than 20 per cent are probably insignificant.

Govaerts (28) has attempted to assay glomerulotubular relationships by comparing the ratio of clearances of creatinine and urea. A marked change in this ratio with little alteration in the creatinine clearance must be interpreted as an indication of variations in the back diffusion of urea. More subtle changes seem hardly interpretable. This ratio either fell or rose during the infusion of albumin in our series and returned to its initial value in all but two instances at the end of the experimental period.

Of much greater significance, in the light of the so-called "forward failure" theory of edema formation, which relates edema to a decrease in glomerular filtration, is the lack of consistency in the pattern of change of either creatinine or urea clearances. Not only was there no consistent rise in rate of clearance during the albumin infusion, but there was a fall in some and no change in others. A correlation between the excretion of salt and the clearances of creatinine and urea was attempted. In S. S. it is to be noted that although the clearances of creatinine remained unchanged the excretion of salt varied greatly, and although the clearance rate rose in E. H., there was no change in the rate of excretion of sodium. Only in P. C. does there seem to be a simultaneous increase in both creatinine clearance and excretion of salt. However, the extremely small urine volume of $39 \mathrm{cc}$. in period II greatly magnifies the possibility of error, and when, in order to obviate this, periods II and III are combined, there is a slight fall in the rate of filtration.

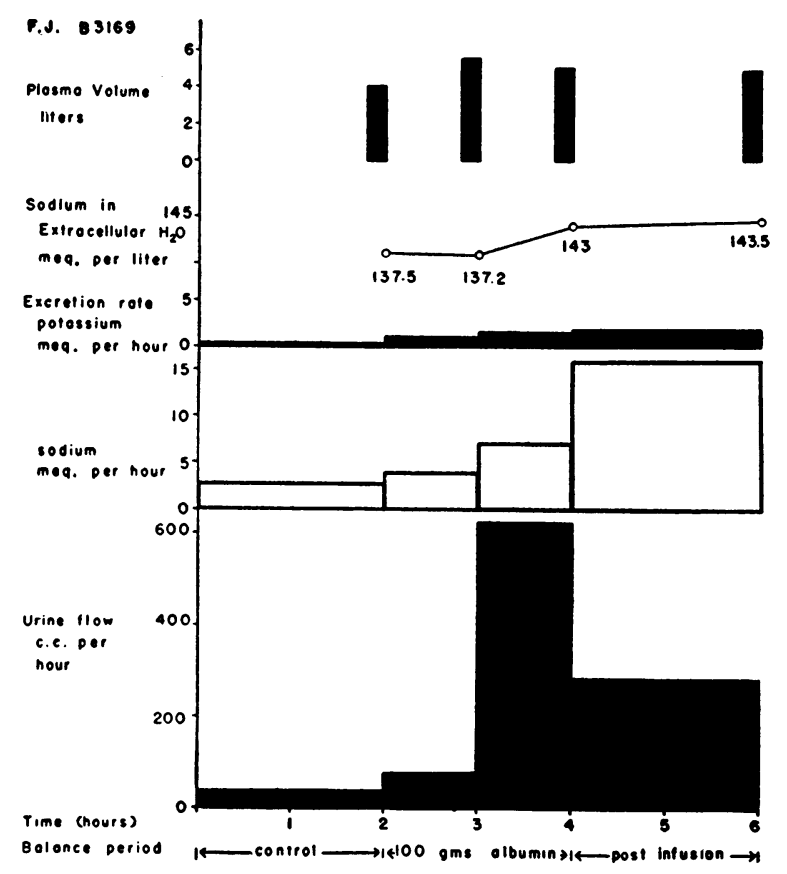

Fig. 4. The Sequence of Events in a Diuresis InDUCEd By Albumin

In this case excretion of a hypotonic urine during the third hour results in a rise in the concentration of serum sodium and an enhanced excretion of salt in the last two hours. 
The N.P.N. concentration in the blood remained unchanged in all cases.

The sequence of events. In those cases in which the sequence of events during the infusion of albumin was analyzed (Figure 4) it appeared that initially there was a profuse diuresis in which water was lost far in excess of sodium. The resultant elevation of the concentration of sodium in the extracellular fluid was associated with a diuresis of salt. Both normal individuals and those edematous patients who did not respond to albumin with an augmented water excretion had no changes in concentration of serum sodium and no increase in rate of excretion of sodium. P. C. illustrates what may occur if the initial output of urine, even if increased, contains a high concentration of salt. Since the urine is not hypotonic there is no elevation in serum sodium and therefore no increase in the output of salt. In all probability, since P. C.'s control urine contained more sodium than is generally found in patients with edema, she was in the process of spontaneously delivering her edema when studied. Although in Figure 5 it appears that the diuresis of water and salt

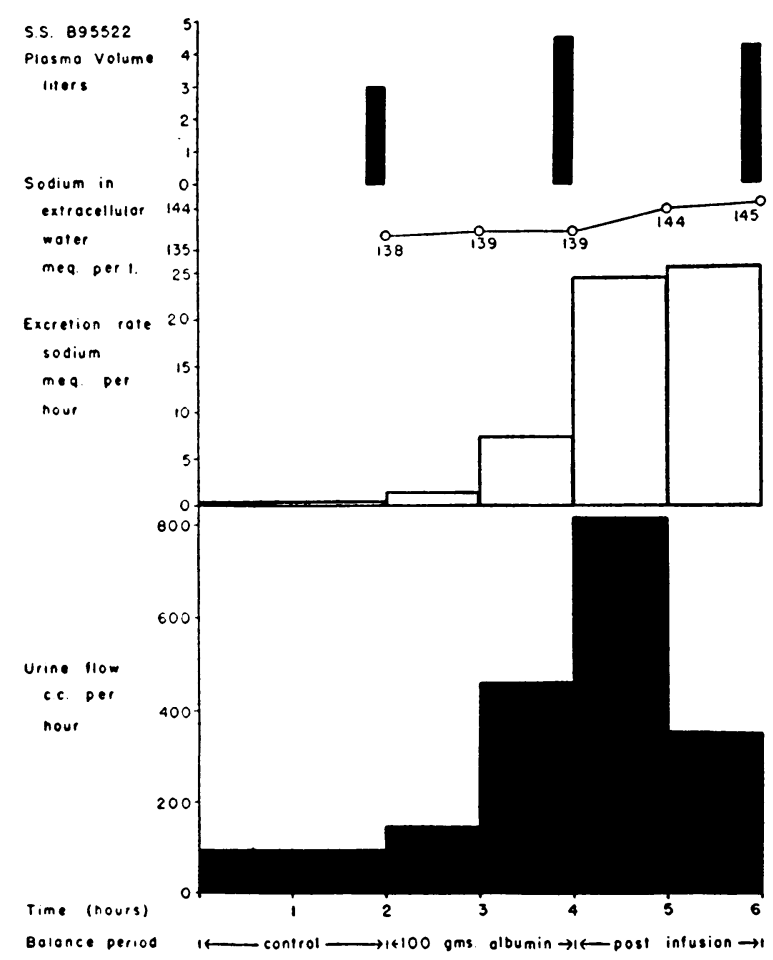

Fig. 5. The Sequence of Events in this Patient is Such That Increased Excretion of Water and Salt Appear to Occur Simultaneously occurred simultaneously, it is possible that if sera and urines had been obtained at more frequent intervals a sequence of events similar to that in F. J. would have been demonstrated.

\section{DISCUSSION}

In the years since 1917 when A. A. Epstein (29) first applied Starling's hypothesis to a brilliant analysis of the pathogenesis of nephrotic edema there had been little experimental evidence offered to challenge this concept. An even firmer footing was established for this theory when Leiter (30) and later Barker (31) demonstrated the sequence of hypoproteinemia, lowered colloid osmotic pressure, transudation, and edema in dogs. More recently Peters (32) has expanded this sequence in an attempt to explain other states of generalized edema. He has suggested that a fall in effective blood volume is the common denominator, whether induced by a reduction in colloid osmotic pressure or by an increase in venous pressure, and that this, perhaps mediated through the adrenal cortex, leads to the retention of salt, which in turn stimulates secretion of anti-diuretic hormone, thirst and ultimately retention of water and edema.

In general the experience of all of those working with albumin would tend to lend partial support to this explanation of the mechanism of the formation of edema. For certainly the first portion of the sequence outlined can be reversed when colloid osmotic pressure is elevated. However, in an attempt to discard the applicability of Starling's hypothesis, much has been made of the well known observations that spontaneous diuresis in a nephrotic may occur in the absence of an elevation in the concentration of albumin.

That this is not necessarily a tenable objecttion is evident from an analysis of the above data and those of Luetscher (6). It is obvious that changes in the concentration of albumin are inversely related to changes in plasma volume. If then, as Lepore (33) intimates, the primary event in a spontaneous diuresis is an increase in colloid osmotic pressure, the resultant expansion of plasma volume will mask any rise in concentration of albumin. Only if the diuresis exceeds the increase in plasma volume will the concentration of albumin rise; the total circulating albumin is undoubtedly increased. 
The dynamic or kinetic nature of colloid osmotic pressure as contrasted with its function merely as a static measurement is further illustrated by a consideration of the fact that the most hypoalbuminemic individuals had the greatest percentage increase in plasma volume. This occurred in the presence of a rise in calculated colloid osmotic pressure which was similar to that noted in the other cases studied. Again this calculated rise would have been greater had the plasma volume not expanded more in the group with the lowest initial concentration of albumin.

Scatchard, Batchelder, and Brown (25) have demonstrated that the osmotic efficiency of albumin is greater at lower concentrations. It is also conceivable that the plasma volume is lowest in the most hypoalbuminemic patients, since they may be forming edema at a faster rate. This would result in a much smaller volume of distribution of the administered albumin and a greater rise in concentration of albumin and colloid osmotic pressure. Consequently, the increase of plasma volume would exceed that of other patients.

The average number of cubic centimeters of fluid drawn into the vascular tree by each gram of albumin, or osmotic efficiency, is approximately equal in all reported studies. Despite the great variability in the results, the average value obtained in these studies was close to those previously reported. Scatchard (25) has arrived at this same figure for the osmotic efficiency of one gram of albumin by in vitro measurements. In view of the many interdependent factors involved in the establishment of osmotic pressure and the wide variations in values obtained clinically, it is remarkable that Scatchard's value can be duplicated in the body.

Since one of the prime purposes of this study was to attempt to elucidate some of the mechanisms involved in the formation of edema, it was thought that a detailed analysis of the sequence of events during the delivery of edema might add to the understanding of the problem. Peters (32) has presented reasons why the retention of salt should precede the retention of water in the production of edema. We have noted that albumin first induced a diuresis of water and that augmented excretion of sodium followed only if the concentration of sodium rose in the serum. This, then, is a reversal of the sequence referred to above. It in no way, as Peters (34) suggests, invalidates the basic premise that sodium chloride is of primary importance in edema formation. On the contrary, it appears logical to think that the delivery of edema might represent a mirror image of its production. Rytand (35) reports a similar sequence in the spontaneous diuresis of a nephrotic while Hall (36) mentions increases in concentration of serum sodium in one of his papers.

The primary diuretic action of concentrated albumin is therefore to promote a diuresis of water. Only if water is excreted sufficiently in excess of salt to elevate the concentration of sodium in the extracellular compartment is there an increased excretion of sodium.

It is not at all clear how albumin induces a diuresis of water. Nor is it clear why some edematous patients, even when hypoalbuminemic, do not respond with an enhancement of water excretion when albumin is administered. Armstrong's (10) suggestion that a sustained increase in plasma volume stimulates diuresis is not always true, since normal individuals and some patients with similar increases in plasma volume do not have augmented rates of excretion of water.

In their experiments on normals, Welt and Orloff $(12,23)$ suggest that contraction of interstitial fluid below normal may be a conditioning factor in preventing water diuresis in nonedematous subjects. They postulate, alternatively, that an equilibrium may exist between elevations in colloid osmotic pressure tending to simulate dehydration and thereby initiating retention of water, and increase in plasma volume acting in an opposing fashion. What the role of colloids alone is in eliciting the excretion of anti-diuretic hormone is not yet understood. It would seem that some such interplay between the action of the antidiuretic hormone, the expansion of plasma volume and the contraction of the volume of interstitial fluid, may condition the response of the kidneys to the administration of albumin.

In recent years numerous investigators have attached considerable significance to the effect of changes in the rate of glomerular filtration on the excretion of electrolytes, notably sodium. It has even been suggested that the increase in the rate of glomerular filtration in nephrotics, which some have noted following the administration of albu- 
min, is the cause of the augmentation of sodium excretion (13). Since edematous nephrotics occasionally have greater than normal clearances of inulin, it is difficult to see how a further increase in filtration can induce an increased excretion of sodium. It is much more reasonable to assume, as Briggs (37) and others have done with respect to congestive heart failure, that the reabsorption of sodium by the tubules is the prime factor in the retention of salt in all generalized states of edema. In our experiments the clearance of creatinine did not increase necessarily when albumin was injected.

Peters (34) has stated that the excretion of sodium is related directly to its concentration in the serum water in adequately hydrated individuals. Under these conditions hypertonic saline not only inhibits anti-diuretic hormone and causes a diuresis of water but it also increases the excretion of salt. Perhaps a similar mechanism exists in the patients with nephrosis and toxemia of pregnancy reported here since, when the concentration of sodium in the extracellular water rises in these edematous individuals, who are presumably well hydrated with respect to their interstitial space, there occurs an inhibition of the reabsorption of sodium. Green and Farah (38) have suggested that cellular dehydration may be the stimulus to salt excretion in dogs infused with sodium chloride solutions. This also has been hypothesized in man by Seldin and Tarail (39). Whatever the basic mechanism may be, it is clear that salt excretion was increased in the present studies only when an elevated concentration of sodium in the serum might have withdrawn water from cells.

\section{SUMMARY AND CONCLUSIONS}

1. The administration of concentrated saltpoor albumin resulted in a diuresis of both water and salt in three patients with the nephrotic syndrome and in one patient with a toxemia of pregnancy.

2. The changes in concentration of albumin in the serum were inversely related to the increase in plasma volume.

3. The osmotic efficiency of albumin was greater in the patients with the lowest initial concentrations of albumin in the serum.

4. There were no significant shifts of electrolytes within the body, despite changes in the vol- ume of extracellular fluids when albumin was injected.

5. Glomerular filtration rate as measured by the clearance of endogenous creatinine did not change consistently.

6. Albumin first induced a diuresis of water. Only if this resulted in an increase in the concentration of serum sodium was salt excretion augmented.

7. Edema in nephrosis and in some patients with toxemia of pregnancy is related to both a decrease in colloid osmotic pressure and to increased tubular reabsorption of salt and water.

\section{ACKNOWLEDGMENT}

We should like to express our appreciation to Dr. John P. Peters for his guidance throughout this study and to Miss Pauline Hald for her generous assistance.

\section{BIBLIOGRAPHY}

1. Cohn, E. J., The history of plasma fractionation, in: Advances in Military Medicine, 1948, Volume I, 364. Little Brown and Co., Boston.

2. Luetscher, J. A., Jr., The effect of a single injection of concentrated human serum albumin on circulating proteins and proteinuria in nephrosis. J. Clin. Invest., 1944, 23, 365.

3. Thorn, G. W., Armstrong, S. H., Jr., Davenport, V. D., Woodruff, L. M., and Tyler, F. H., Chemical, clinical, and immunological studies on the products of human plasma fractionation. XXX. The use of salt-poor concentrated human serum albumin solution in the treatment of chronic Bright's disease. J. Clin. Invest., 1945, 24, 802.

4. Eder, H. A., Chinard, F. P., Lauson, H. D., Greif, R. L., Hiller, A., Cotzias, G. C., and Van Slyke, D. D., Studies on the pathogenesis of nephrotic edema. J. Clin. Invest., 1949, 28, 779.

5. Janeway, C. A., Gibson, S. T., Woodruff, L. M., Heyl, J. T., Bailey, O. T., and Newhouser, L. R., Chemical, clinical, and immunological studies on the products of human plasma fractionation. VII. Concentrated human serum albumin. J. Clin. Invest., 1944, 23, 465.

6 Luetscher, J. A., Jr., Hall, A. D., and Kremer, V. L., Treatment of nephrosis with concentrated human serum albumin. I. Effects on the proteins of body fluids. J. Clin. Invest., 1949, 28, 700.

7. Patek, A. J., Jr., Mankin, H., Colcher, H., Lowell, A., and Earle, D. P., Jr., The effects of intravenous injection of concentrated human serum albumin upon blood plasma, ascites, and renal function in three patients with cirrhosis of the liver. J. Clin. Invest., 1948, 27, 135.

8. Thorn, G. W., Armstrong, S. H., Jr., and Davenport, V. D., Chemical, clinical, and immunological stud- 
ies on the products of human plasma fractionation. XXXI. The use of salt-poor concentrated human serum albumin solution in the treatment of hepatic cirrhosis. J. Clin. Invest., 1946, 25, 304.

9. Faloon, W. W., Eckhardt, R. D., Murphy, T. L., Cooper, A. M., and Davidson, C. S., An evaluation of human serum albumin in the treatment of cirrhosis of the liver. J. Clin. Invest., 1949, 28, 583.

10. Armstrong, S. H., Jr., Mechanisms of action of serum albumin therapy in internal medicine. Am. J. Med., 1948, 4, 390.

11. Goodyer, A. V. N., Peterson, E. R., and Relman, A. S., Some effects of albumin infusions on renal function and electrolyte excretion in normal man. J. Applied Physiol., 1949, 1, 671.

12. Welt, L. G., and Orloff, J., Effects of infusion of albumin on the excretion of water and electrolytes in normal subjects. J. Clin. Invest., 1949, 28, 818.

13. Bradley, S. E., and Tyson, C. J., The "nephrotic" syndrome. N. Eng. J. Med., 1948, 238, 223, and 260.

14. Gibson, S. T., Blood and its derivatives. N. Eng. J. Med., 1948, 239, 544, and 579.

15. Elkinton, J. R., and Taffel, M., Prolonged water deprivation in the dog. J. Clin. Invest., 1942, 21, 787.

16. Hald, P. M., The flame photometer for the measurement of sodium and potassium in biological materials. J. Biol. Chem., 1947, 167, 499.

17. Milne, J., Serum protein fractionation: A comparison of sodium sulfate precipitation and electrophoresis. J. Biol. Chem., 1947, 169, 595.

18. Elkinton, J. R., Danowski, T. S., and Winkler, A. W., Hemodynamic changes in salt depletion and in dehydration. J. Clin. Invest., 1946, 25, 120.

19. Peters, J. H., The determination of creatinine and creatine in blood and urine with the photoelectric colorimeter. J. Biol. Chem., 1942, 146, 179.

20. Van Slyke, D. D, Determination of urea by gasometric measurement of the carbon dioxide formed by the action of urease. J. Biol. Chem., 1927, 73, 695.

21. Eisenman, A. J., Mackenzie, L. B., and Peters, J. P., Protein and water of serum and cells of human blood, with a note on the measurement of red blood cell volume. J. Biol. Chem., 1936, 116, 33.

22. Govaerts, P., Quotient albumines-globulines et pression osmotique des proteines du serum. Compt. rend. Soc. de biol., 1926, 95, 724.

23. Welt, L. G., and Orloff, J. Unpublished studies.

24. Fine, J., Experimental traumatic shock, in: Advances in Military Medicine, 1948, Volume I, 341. Little Brown and Co., Boston.

25. Scatchard, G., Batchelder, A. C., and Brown, A., Chemical, clinical, and immunological studies on the products of human plasma fractionation. VI. The osmotic pressure of plasma and of serum albumin. J. Clin. Invest., 1944, 23, 458.

26. Heyl, J. T., Gibson, J. G. 2nd, and Janeway, C. A., Studies on the plasma proteins. V. The effect of concentrated solutions of human and bovine serum albumin on blood volume after acute blood loss in man. J. Clin. Invest., 1943, 22, 763.

27. Waterhouse, C., Bassett, S. H., and Holler, J. W., Metabolic studies on protein-depleted patients receiving a large part of their nitrogen from human serum albumin administered intravenously. J. Clin. Invest., 1949, 28, 245.

28. Govaerts, $P$., The ratio of creatinine clearance to urea clearance in toxic nephropathies. Stanford M. Bull., 1948, 6, 71.

29. Epstein, A. A., Concerning the causation of edema in chronic parenchymatous nephritis; method for its alleviation. Am. J. M. Sc., 1917, 154, 638.

30. Leiter, L., Experimental nephrotic edema. Arch. Int. Med., 1931, 48, 1.

31. Barker, M. H., and Kirk, E. J., Experimental edema (nephrosis) in dogs in relation to edema of renal origin in patients. Arch. Int. Med., 1930, 45, 319.

32. Peters, J. P., The role of sodium in the production of edema. N. Eng. J. Med., 1948, 239, 353.

33. Lepore, M. J., Acacia therapy in nephrotic edema. Ann. Int. Med., 1937, 11, 285.

34. Peters, J. P., The significance of serum sodium. McGill Med. J., 1949, 18, 130.

35. Rytand, D. A., Chronologic separation of water and chloride diuresis in nephrotic syndrome. Am. J. Med., 1948, 4, 624.

36. Hall, A. D., and Luetscher, J. A., Jr., Renal disease. N. Eng. J. Med., 1948, 239, 621.

37. Briggs, A. P., Fowell, D. M., Hamilton, W. F., Femington, J. W., Wheeler, N. C., and Winslow, J. A., Renal and circulatory factors in the edema formation of congestive heart failure. J. Clin. Invest., 1948, 27, 810.

38. Green, D. M., and Farah, A., Influence of sodium load on sodium excretion. Am. J. Physiol., 1949, 158, 444.

39. Seldin, D. W., and Tarail, R., Effect of hypertonic solutions on metabolism and excretion of electrolytes. Am. J. Physiol., 1949, 159, 160. 